\title{
Beszámoló
}

\section{A PTE 650 KŐRÖSI CSOMA SÁNDOR EMLÉKEXPEDÍCIÓ INDIÁBAN}

\section{THE 650 YEARS OLD UNIVERSITY OF PÉCS'S SÁNDOR KŐRÖSI CSOMA REMEMBRANCE EXPEDITION IN INDIA}

\author{
Pap Norbert \\ tanszékvezető egyetemi docens, Pécsi Tudományegyetem Természettudományi Kar Politikai földrajzi, Fejlődés és Regionális \\ Tanulmányok Tanszéke \\ pnorbert@gamma.ttk.pte.hu
}

\begin{abstract}
ÖSSZEFOGLALÓ
A Pécsi Tudományegyetem kutatói terepi vizsgálatokat végeztek Indiában az indiai magyar emlékezet tárgyában. Az expedícióra 2016 áprilisában került sor. Jelen beszámoló bemutatja, hogy milyen szakmai területeken születtek új eredmények, és ezek milyen módon kerültek a közönséghez.
\end{abstract}

\section{ABSTRACT}

Scholars of the University of Pécs organised a fieldwork research in India on the field of the Hungarian remembrance in India. The expedition was implemented in April of 2016. The short report describes the professional contribution of the participants and the outputs.

Kulcsszavak: Kőrösi Csoma Sándor, India, emlékezet

Keywords: Alexander Csoma de Kőrös, India, remembrance

A Pécsi Tudományegyetem Földtudományok Doktoriskola oktatói 2016. március 31. és április 13. között Körösi Csoma Sándor nevét viselö emlékexpedíciót szerveztek Indiába, hogy közösen gondolják át az indiai magyar emlékezetet és emlékezetpolitikát. A programot dr. Pap Norbert és dr. Wilhelm Zoltán szervezték és vezették. A doktoriskolához kötődő oktatók, a Geopolitika doktori programot vezető, az indiai Goa történelmi szerepét vizsgáló dr. Szilágyi István, az iszlámmal és biztonságpolitikával foglalkozó dr. N. Rózsa Erzsébet, a különböző 
civilizációs hátterű nemzeti szervezeti kultúrákat kutató dr. Jarjabka Ákos, a kulturális turizmus szakértő dr. Gonda Tibor és a magyar arisztokrácia 19-20. századi indiai utazásait vizsgáló dr. Kitanics Máté csatlakoztak a kezdeményezéshez. Dr. Ács Marianna a kereszténység indiai helyzetével, az európai és amerikai missziós munkával, különösen pedig a magyar hozzájárulással foglalkozott, míg Nemes Viktória doktorandusz az indiai nőkérdés egyes aspektusaira reflektáló doktori kutatásaihoz szerzett helyi tapasztalatokat, intézményi kapcsolatokat és kutatási ötleteket. Dr. Wilhelm Zoltán, aki tizenöt éve kutatja India földrajzát, és ezalatt páratlan terepi tapasztalatokra tett szert, igen magas színvonalú szakmai vezetést biztosított, miközben a helyi intézményi találkozók megszervezésére is kiemelt hangsúlyt fordított. Ezen túl biztosította a magyar indiai jelenlétre, köztük a Körösi Csoma Sándorra vonatkozó ismereteket. Dr. Pap Norbert az indiai magyar emlékezethez kapcsolódó kutatási programot szervezte meg, és a talán leghíresebb magyar muszlim, Germanus Gyula és felesége, Hajnóczy Rózsa indiai tartózkodásával, az arabista tudósnak az iszlámra való áttérésével kapcsolatos emlékezeti kérdésekkel foglalkozott.

Az utazás során mintegy féltucatnyi magyar emlékhelyet kerestek fel, és mérték fel ezek helyzetét, általános állapotát, valamint hogy magyar emlékezeti szempontból milyen üzenetet közvetítenek és milyen színvonalon. Vizsgálták, hogy milyen fejlesztéseket igényelnek, illetve hogy a helyi kontextusban milyen szerepet és jelentőséget töltenek be. Az indiai-európai viszonylatot általában megterheli a koloniális idők emlékezete, ezzel szemben a magyarság indiai kapcsolatai jellegükben nem az elnyomáshoz, hanem a tudományhoz, a politikához és a müvészetekhez kötődnek. A magyarok ázsiai eredete, a magyarság ázsiai őshazájának kutatása folyamatosan megjelenik az India iránti érdeklődésünkben. Ez egy különös és egyedi vonásokkal rendelkező kapcsolatrendszert alapozott meg. India az elmúlt évtizedekben szegény és elnyomott gyarmati területből a világ egyik legfontosabb országává vált, amelyben igen nagy fejlödési potenciál van. A magyar indiai emlékezetpolitika egy olyan páratlan lehetőségeket hordozó fejleszthető és fejlesztendő terület, amely Magyarország pozícióit Indiában jelentősen tudja javítani, nagyobb mértékben, mint az a méretünkből és fejlettségünkből következne.

Az utazás végén, az újdelhi Magyar Tájékoztatási és Kulturális Központban tartott workshop keretében a résztvevők értékelték a tapasztalatokat, és megfogalmazták a „Kőrösi Csoma Sándor Magyar-Indiai Zarándokút” koncepcióját. Ez egy, az indiai magyar emlékhelyeket összegyüjtő, illetve összekapcsoló projekt, melynek egyes állomásai révén a kulturális összekapcsolódás magas intenzitással valósulhat meg. A nagy távolságokra és az erőforrások szükösségére tekintettel ezeket az információkat és tartalmakat csak smart megoldásokkal érdemes létrehozni és eljuttatni a felhasználókhoz. Megegyeztek abban is, hogy a felhasználás nem elsősorban turisztikai, hanem kulturális diplomáciai lehet, bár érdemes len- 
ne a magyarok indiai turisztikai útjaiba egyes elemeket beépíteni, ezáltal ezeket a helyeket és eseményeket megerősíteni a magyar nemzeti emlékezetben.

Az út mindezek mellett alkalmat kínált arra is, hogy intézményi kapcsolatokat építsen ki a csoport a mumbai magyar főkonzulátussal, egy goai magánalapítású felsőoktatási intézménnyel, Kolkatában a bengáli Ázsia Társasággal, valamint, hogy az emlékezés és a tisztelet koszorúit elhelyezze Körösi Csoma Sándor dardzsilingi sírjánál és az emlékezetére emelt kopjafánál. Az utazásról film és számos fotó is készült. Az egyes vizsgálati témákról tanulmányok születtek, amelyekből 2018 februárjában önálló kötet jelenik meg. Az útról készült filmet Pécsett a Mahatma Gandhi Gimnáziumban mutatták be.

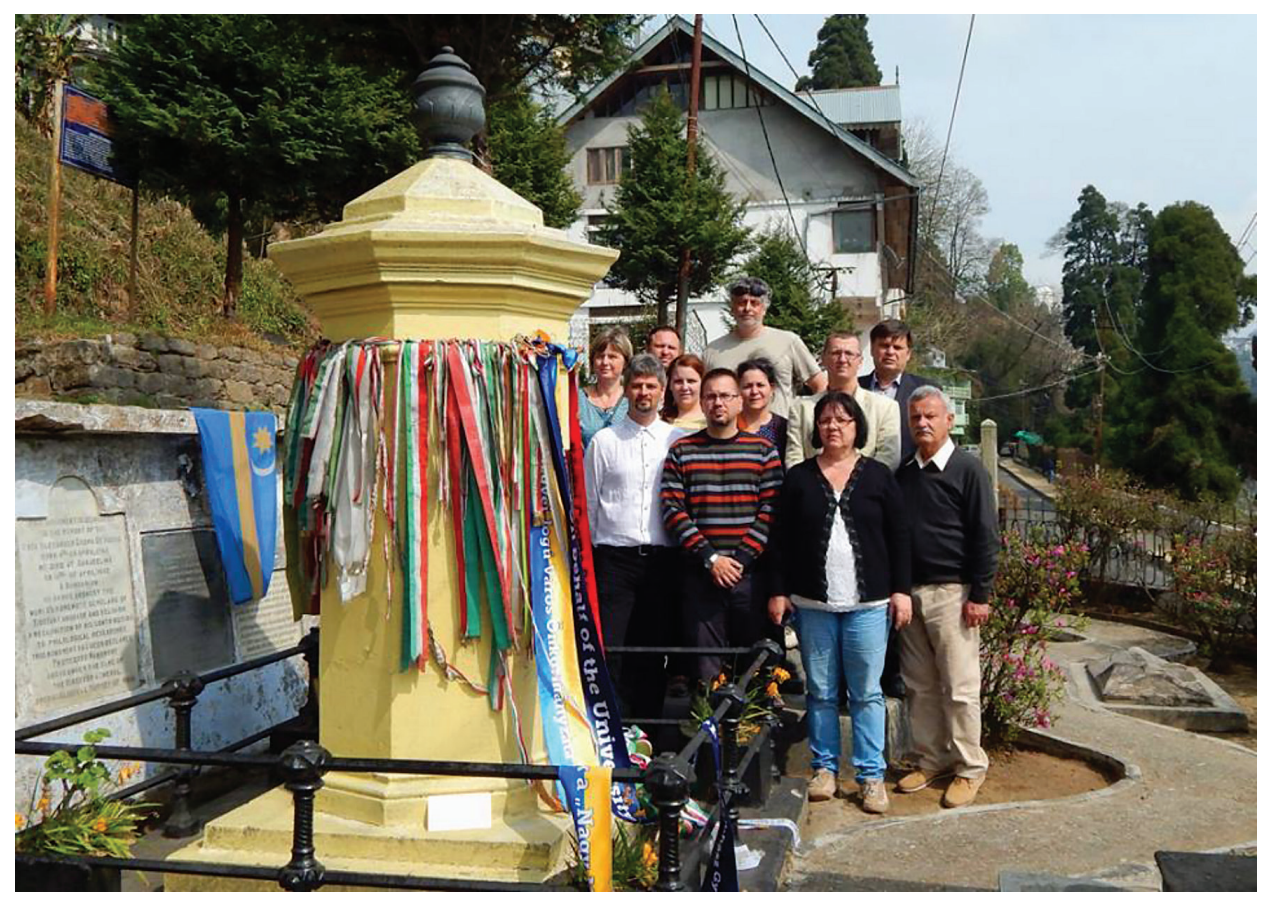

Az expedíció tagjai Körösi Csoma Sándor sírjánál, Dardzsilingban 